\title{
Teacher's and Students' Perspectives Regarding the Reading Materials in the Extensive Reading and Writing Class
}

\author{
Eunike Listyoyanti Suseno, Henny Putri Saking Wijaya \\ English Department, Faculty of Letters, Petra Christian University, Siwalankerto 121-131, Surabaya 60236, \\ INDONESIA \\ Email: eunikels21@gmail.com, hennypsw@ petra.ac.id
}

\begin{abstract}
This qualitative study aimed to know the teacher's and the students' perspectives regarding the reading materials in the Extensive Reading and Writing (ERW) class. The study used the theory of Extensive Reading Principles by Day and Bamford (2002). The study also tried to draw the similarities and differences between their perspectives. The subjects of the research were 10 students and 1 teacher from ERW class in the English Department of Petra Christian University, Surabaya. Semi structured interviews were used to explore their perspectives toward the reading materials of ER. The findings showed that the teacher and the students had various perspectives regarding the reading materials in ERW class. In conclusion, the provision of reading material was not really in line with the ER principles because of the unique nature of ERW class. For the future research, the writers suggested doing quantitative research with a variety of subjects for more generalizable result.
\end{abstract}

Keywords: extensive reading, implementation, perspectives, students, teachers

\section{INTRODUCTION}

Extensive Reading (ER) is defined as "the independent reading of a large quantity of material for information or pleasure. The primary aim of ER programs, according to Day and Bamford, is to get students reading the second language and liking it" (Day, Bamford, Renandya, Jacobs, \& Yu, 1998, p.188). Extensive reading is considered to be an effective way to help the school or university students to increase the students' literacy level (Anandari \& Iswandari, 2019).

According to Day and Bamford (2010), ER is very beneficial to be practiced in the EFL classroom. Day and Bamford's (2010) study shows that ER can change the students' attitudes toward reading in English. In their study, Day and Bamford (2010) also mention that after joining the ER program, the learners become eager readers. Elley (1991), as cited in Day and Bamford (2010) reports that the students developed "very positive attitudes toward books as they raised their literacy levels in English". Some studies, as cited in Day and Bamford (2010), state that ER can contribute to overall language proficiency. Some studies also show that ER can increase vocabulary knowledge. Because of the benefits of ER, the program is worth studying.

Additionally, according to Barnes \& Lock (2013), it is also important to understand students' and teachers' perspectives about classroom practice. The purpose is to know how to approach and improve the effectiveness of the class. As cited in Barnes \& Lock (2013), understanding the 
similarities and differences of the teachers' and students' perspectives about the classroom practice is necessary because if they have a different perspective about what should occur in the classroom practice, it could demotivate the teachers and the students as well. If the teachers and the students are not motivated to attend the class, the class will be ineffective. Therefore, to prevent the class from being ineffective, it is necessary to study the similarities and differences of teachers' and students' perspectives in any classroom (Barnes \& Lock, 2013).

This research attempted to find out the teacher's and the students' perspectives regarding the reading materials in the extensive reading and writing class; therefore, in this research the writers referred to the 10 principles of Extensive Reading theory by Day and Bamford (2002). In brief, below were the 10 principles of ER by Day and Bamford (2002): (1) The reading material is easy, (2) A variety of reading material on a wide range of topics must be available, (3) Learners choose what they want to read, (4) Learners read as much as possible, (5) The purpose of reading is usually related to pleasure, information, and general understanding, (6) Reading is its own reward, (7) Reading speed is usually faster rather than slower, (8) Reading is individual and silent, (9) Teachers orient and guide their students, and (10) The teacher is a role model of a reader.

However, the writers only focused on the first principle of Extensive Reading namely "the reading material is easy". According to Day and Bamford (2002), the first principle of Extensive Reading specifically makes it different from other ways of teaching the reading of foreign languages. To make the learners read extensively and achieve the desired outcomes, the texts that the learners read must be well within their foreign language reading skills. Beginner readers need to read texts that are comfortable for them, therefore, they need to choose texts that can be understood. Beginner readers should not read text that consists of more than one or more than two unfamiliar words per page. Reading text that consists of more than two unfamiliar words can make the text way too hard to read for beginners.

Day and Bamford (2002) also state that, different from the beginner readers, the intermediate readers should use "the rule of thumb" which means the text they read must not consist of five or more hard words per page. As cited in Day and Bamford (2002, p. 137), Hu and Nation (2000) suggest that "learners must know at least $98 \%$ of the words in a fiction text for unassisted understanding." Day and Bamford (2002) also suggest adjusting the text based on the learners' ability. Fry (1991), as cited in Day and Bamford (2002, p. 137), finds out in his observation that "beginning readers do better with easier materials." That statement is very relatable to the Extensive Reading principle because in Extensive Reading the students need to read autonomously, without any assistance.

Even so, the usage of easy materials in Extensive Reading is controversial (Day \& Bamford, 2002). As cited in Day \& Bamford (2002), some people argue that instead of using easy materials, Extensive Reading should use simplified texts. By using simplified texts, the students will get used to real-world reading. Most importantly, learners need to be motivated to learn and read more in the target language. Therefore, in the Extensive Reading program, the students need to be encouraged to read texts that are suitable to their language ability. By reading the texts that are suitable to their language ability, the students will enjoy the learning process.

\section{METHODS}

This study was a qualitative study. The subject of this study was a teacher (Teacher X) and 10 students (Student A-J) from Extensive Reading and Writing (ERW) class in English Department, 
Suseno, Wijaya: Teacher's and Students' Perspectives Regarding the Reading Materials in the Extensive Reading and Writing Class

Petra Christian University. ERW class was a unique class; therefore, the writers provided information about the class and the Basic Course Outline of the class. Because of the pandemic, the class was held online via Google Meet. The class was held every Friday at 8.30 AM. In Extensive Reading and Writing class, the students were given two kinds of materials that were teacher-selected materials and students-selected materials. During the first until the fifth meeting the students of Extensive Reading and Writing class, the students read the following books:

1. The Necklace (Guy de Maupassant)

2. Cosmopolite in a Café (O. Henry)

3. The Gift of the Magi (O. Henry)

4. The Umbrella (Guy de Maupassant)

5. A Service of Love (O. Henry)

Additionally, outside the class the students were asked to read from an Extensive Reading website namely www.er-central.com. The teacher gave the students freedom to choose their own materials and levels. The teacher gave the students points based on how many words the students read from the website. The students would get maximum participation points if they read more than 40,000 words by the end of the semester.

To get the data from the teacher and 10 students from ERW class, the writers held a semi structured interview. The interview was held twice: the first one was after the first meeting of ERW class (from 21 August until 28 August 2020) and the second one was after the fifth meeting of ERW class (2 October until 9 October 2020). Since the research was conducted during the pandemic and online learning environment, all the interviews were held via Google Meet. To determine the teacher's and the students' perspectives, the writers asked this following question:

For students:

1. Do you think the reading materials given are easy? Why do you think so?

2. What do you think of "easy materials"? Is it good or is it bad? Why do you think so?

3. How did the lecturer manage the materials so they were suitable with your language proficiency?

For teacher:

1. Do you think that the materials that you give to the students are easy? Why do you think so?

2. What do you think of "easy materials"? Is it good or is it bad? Why do you think so?

3. How did you manage the materials so they were suitable with your students' linguistics competence?

To make those questions, the writers combined their own questions with Arifuddin's (2018) list of questions. Therefore, a pilot project was held before the interview to check the effectiveness of the questions. The pilot project was held on 18 August 2020 with 4 students from another ERW class. Meanwhile, for the teacher's list of questions, the writers consulted the questions with a teacher from another ERW class who is also the reading coordinator in English Department.

After completing the transcription of the interview, the writers inputted the data into several tables to make it easier to analyze. The results of the analysis were presented in the findings and discussion section. 


\section{FINDINGS AND DISCUSSION}

In the writers' study towards 10 students and 1 teacher from ERW class in Petra Christian University, the writers found some interesting findings that would be discussed in the following section. The discussions about students' perspectives were described first and then followed by the discussions on teacher's perspectives.

As explained by the principle, the material in ER should be easy; therefore, the writers asked the students whether the text given in ERW class was easy or not. From the first interview with the students, the writers got that 4 out of 10 students thought the materials given in the class were easy. The first interview was held after the students had finished reading their first reading text which was "The Necklace".

"Mostly easy. (1.6.3) ... I'm familiar with most of the language of this story, apart from the few that were not usually spoken every day. (1.6.5)" (Student F)

"Based on what I learn so far, I think it's easy but also challenging. (1.8.2) I think the vocab is pretty easy, there are still some vocabs that I couldn't understand. The sentences are also not really complicated. I think the reading is average. (1.8.3)" (Student $\mathrm{H}$ )

"They're quite easy. (1.10.2) Because the language is quite simple (1.10.3) so I can understand the vocab. (1.10.4)" (Student J)

The students mentioned that the reading materials given were easy to understand mostly because of the language. They thought the vocabulary and the sentences were easy to understand; therefore, they could understand the whole story. These findings were in line with the Extensive Reading Principles by Day and Bamford (2002). Unfortunately, the writers found out that only 4 out of 10 interviewees thought that the reading material was easy. The rest of the interviewees thought that the reading material given was hard.

"Not really (easy) to understand the material (1.1.2) understand the material because there are several words that can't be understood. (1.1.2)..." (Student A)

"Oh at first it is hard because I don't really like to read but I tried to find the summary on the internet. (1.3.5) Actually the material is not hard, but I don't really like to read so I felt bored. (1.3.7)" (Student C)

"... Sometimes it's easy but sometimes it's not easy. (1.7.2) "The Necklace" is hard, I think, because I haven't read it all, just a half. (1.7.3)”' (Student G)

"It's challenging, especially that I don't encounter such stories in my daily life. (1.9.3) I understand the stories but for the vocabulary, sometimes I have to use Google translate. (1.9.4)" (Student I)

There were 4 reasons why the students thought that the reading was hard. Three out of 6 students (students A, B, \& I) said that the reading was hard because of the vocabulary. Those students mentioned that there were French words; therefore, they could not understand the story. Two out of 6 students (students $\mathrm{C} \& \mathrm{E}$ ) said that the reading was hard because they did not really enjoy reading. Student $\mathrm{G}$ mentioned that the reading was hard because he had not finished reading, which resulted in inability to participate in the discussion. Student I mentioned that the reading was hard because the story was unfamiliar.

Those findings were not in line with ER principles by Day and Bamford (2002) because as mentioned by Day and Bamford, the reading should be well within the learners' comfort zone because 
Suseno, Wijaya: Teacher's and Students' Perspectives Regarding the Reading Materials in the Extensive Reading and Writing Class

the purpose of ER was to make the students enjoy the reading and willing to read extensively. Imamura (2002) held a study about the implementation of ER in a university in Japan. The result was the successful learners in ER tend to read books in which the levels were appropriate for the learners. Therefore, it was very important to guide the students to choose books that were not too hard for them, especially in the first meeting of the Extensive Reading course.

Still answering the first question, in the second interview, the students had read "The Necklace", "Cosmopolite in a Cafe", "The Gift of the Magi", "The Umbrella", and "A Service of Love". As an assignment, the students also read from ER website which was (er-central.com). Student $\mathrm{C}, \mathrm{E}, \mathrm{H}$, and $\mathrm{J}$ said that the reading materials were easy. Student D and F also thought the reading materials were easy, but they were getting harder.

"Based on the meetings that I had until now, it's kind of understandable and still easy. But still, sometimes we still have to read more in order to understand the material.

It's not hard because the vocabulary is understandable." (Student $\mathrm{H}$ )

"It's getting harder as time goes on because there are some stories where I had to understand the wide varying of themes each story provides, but overall it was still in the mostly easy range" (Student F)

Student A, B, G, \& I thought that the materials were challenging or hard to understand.

"It was not easy, because there was so much new vocabulary that I had never seen or used before, and there were so many different types of sentences that were unfamiliar to use in daily life. For example, figurative language, idioms, and professional words. (2.2.2) There are also some French words in my reading. (2.2.3)" (Student B)

There were several reasons why the reading materials were seen difficult by the learners. The reasons were because of the vocabulary, the storyline, and because the student read the materials near the deadline (Student G). There were some students who changed their answer in the second interview. For example, student $\mathrm{C}$ and student $\mathrm{E}$ previously said that the material was hard and in the second interview they said the reading materials were easy.

From those answers, the writers could say that "The Necklace" might be too hard to be placed in the first meeting. The topic, the setting, and the language of the short story might surprise the first semester students. Since "The Necklace" was written by Guy de Maupassant, a French writer, the text consisted of French words which made the readers confused. Ideally, the level of the materials should be increased gradually; therefore, an adjustment needs to be made. However, from all of the students' answers regarding the easiness of the materials, all students were referring to the classroom materials. None of them was talking about the reading materials in the website (er-central.com).

For the second question, the writers asked "What do you think of "easy materials"? Is it good or is it bad? Why do you think so?". According to Day and Bamford (2002), the reading materials should be comfortable to the learners, so the writers assumed that the students would prefer to enjoy reading easier materials. That was true because student A, C, D, E, F, G, and H, thought that easy materials were good:

"It is good because we can analyze from the story and we know the characters or maybe the inside of the story. Sometimes I prefer an easier story but maybe sometimes I prefer a more complicated story. (1.1.7)" (Student A) 
"Easy materials, I think it's good. (1.3.10) Because personally I'm not the person to use English as my daily language so I could learn something that I have not learned before like something I have been missing I think. (1.3.11) ... If I can choose, I will choose the harder one because I need to challenge myself in the work field later. (1.3.15)" (Student C)

"It is good actually (1.4.11) because easy materials can motivate students to learn more. ...” (Student D)

“... Easy materials make me more comfortable. (1.5.14)” (Student E)

Some of those students thought easy materials were good, but they still preferred to have hard materials like student $\mathrm{A}$ and $\mathrm{C}$. The writers were also quite surprised with the results because there were actually some students (student B \& I) who preferred to have a hard one instead of an easy one:

"I think it is bad (1.2.6) because the easy one can't make us improve our skill. (1.2.8)" (Student B)

"I prefer hard so I can upgrade my skills in reading. (1.9.6)" (Student I)

This was actually related to the $10^{\text {th }}$ principle of ER which explained that these kinds of students might believe in "no pain in reading, no gain in reading". These students will not understand that easy and interesting texts can also help them to be better readers. Therefore, the introduction of Extensive Reading is crucial and needs to be done carefully (Day \& Bamford, 2002).

In the second interview, the answers shifted from easy materials were good into both easy and hard materials were good if they were in balance or used correctly at the right time. Those answers were in line with the theory of ER that the reading should be well within the learners' level. According to Imamura (2020), by reading books with appropriate level, the reading will be more enjoyable. Therefore, it was not necessary to learn only from hard books.

"In my opinion, it depends on the situation that we had. It will be great when we do the test and there are more advantages. But, it will be very bad for us to improve our abilities, because the easiest things will not help us to learn and improve our abilities. (2.2.4)" (Student B)

"It's rather good, but sometimes we need an upheaval course to challenge and force us to improve the reading level (2.8.2)" (Student $\mathrm{H}$ )

"If you're a new university student, it's better to get the easy one. But the difficulty level can get more difficult along the time. (2.10.5)" (Student J)

For the third question, the writers asked the students whether the lecturer managed the materials so they were suitable for the students or not. That question derived from Day and Bamford's study (2002) that explained that in ER program the students need to be encouraged to read texts that are suitable to their language ability. The reason was because by reading the texts that are suitable to their language ability, the students will enjoy the learning process. However, in practice, all of the students didn't feel like there was any form of adjustment to their own language level in the class.

"The teacher hasn't tested us. (1.2.15) We read the same kind of text. (1.2.16)" (Student B)

"The teacher has not tested us. (1.5.16) The materials given are not suitable for my own language ability. (1.5.18)" (Student E)

Luckily, even though the students were not tested before the materials were given, some students felt that the material was actually suitable for them. 
Suseno, Wijaya: Teacher's and Students' Perspectives Regarding the Reading Materials in the Extensive Reading and Writing Class

"The teacher didn't test us, (1.8.8) but I think yeah it's suitable for me. (1.8.7)" (Student H) "Actually suitable, it's actually suitable, it's just I don't feel the teacher was watching over the language proficiency (1.6.10)" (Student F)

In the second interview, the students still agreed that the teacher didn't test them. Some students pointed out that the materials given in the class by the teacher were not too hard and too easy so everyone can understand the texts.

"I think she didn't test us, but she chose materials which everyone could understand (2.8.2)" (Student H)

"I think the lecturer does not give too easy or too difficult materials so that they are suitable for each student. (2.10.7) I think the materials are suitable for me. (2.10.8)" (Student J)

It was true that the learners were not tested before the materials were given in the class because the materials were compulsory, and were not adjusted to each student level. However, outside the class, or through ER central website, there was a diagnostic test to measure the students reading and listening skills in order to find reading materials that were suitable for their level. The other students did not talk about that, but student $\mathrm{F}$ talked about the diagnostic test in the second interview.

"She tested our language proficiency via a diagnostic test, so the reading text that is given in class is suitable with my level." (Student F)

In this following paragraphs, the writers would like to discuss the findings regarding the teacher's perspectives regarding the reading materials in ERW class. As mentioned below, according to the principles of Extensive Reading, the text given to the students must be easy to understand and read, or well within the learners' competency (Day \& Bamford, 2002). Therefore, as the first question, the writers checked whether the lecturer thought the materials given to the students were easy or not.

"In my opinion, it is in accordance with the level of competence. Easy and difficult depends on the level of the competence of the students. Any teachers will find materials that are in accordance with the level of competence. (1.11.1)"

According to the teacher, the difficulty of the text depends on the learners, but the lecturer tried to give reading materials that are suitable for the general level of the first semester students. In the second interview, the lecturer also emphasized the same thing.

"Well, it depends easy or not because we prepare it for the level of the students. So, we consider the level of the students and they are in the first semester, right? (2.11.1)"

There were controversies regarding easy materials in ER. Some people thought that it was good to have easy materials because it would be more enjoyable, but it was not challenging enough. Some students also have different preferences regarding the difficulty of the materials. As the second question, the writers asked the teacher's perspective regarding easy materials in Extensive Reading and Writing class, and whether it is good or not. Below is the teacher's answer:

"Of course, they have to enjoy their reading materials. When the materials are easy sometimes the students get bored. If it is difficult, the students can get bored as well and they don't want to read. I think, the levels should be their level of competence, not easy or 
difficult. It also depends on whether or not the materials are relevant to the students' life... (1.11.3)"

The answer was actually closely related to the principle of ER that the materials should be "well within" the learners' ability which means it should be not too easy and not too hard as well. Day and Bamford (2002) did not mention that the materials need to be relevant to the students' life, but the answer did make sense because the text would be easier to understand if it was related to the daily life of the reader.

Additionally, a study by Imamura (2018) supported Teacher X's answer. In Imamura's study, the learners were asked to choose books that were suitable to their own level. One of the participants of Imamura's study who was Participant E changed his/her books several times before finally finding the books that he/she could understand and enjoy.

"- A little difficult ("I did not realize I had chosen difficult books") => easy books => Later, "I found the easy books boring" => a slightly higher difficulty." - Participant E (Imamura, 2020, p. 131).

As mentioned above, participant $\mathrm{E}$ chose a hard book at first and she found that was too difficult. After that, when she changed to an easier book, it turned out that the book was boring. Then participant $E$ changed to a slightly higher difficulty and ended up finishing that book. That supported Day and Bamford's (2002) findings that the reading should be well within the learners' ability and also supported Teacher X statement that the reading should be on the students' levels of competence.

Choosing the suitable material for the students was really important in the ER program. Therefore, in the third question the writers asked how the teacher chose the materials that suited the students' linguistic competence.

\section{"I think of course I consult books (1.11.4)"}

In the second interview the lecturer explained more about the answer:

"Well, of course I didn't actually choose, it's the coordinator who chose the materials for the students. ... About consulting books, because the materials are short stories especially canonized short stories of course we are not writing at the moment, but we took from the source, so we consulted books. So the materials are from a very authentic source. (2.11.3) ... I think the level of the text is suitable for the level of first semester students in general. (2.11.4)"

However, choosing the materials based on "the level of first semester students in general" did not seem to work since some students still considered the reading materials were hard. In Imamura's study (2020), it was shown that the preference of someone when choosing a book could be as specific as "Books (preference): thin, interesting, and containing pretty pictures" - Participant E (Imamura, 2020, p. 131). The Extensive Reading and Writing course chose to provide books for the students inside the class; therefore, the students could not choose which materials suited the students best. If the materials were given from the teacher, at least it should be more various in genres or display because each student was different. 
Suseno, Wijaya: Teacher's and Students' Perspectives Regarding the Reading Materials in the Extensive Reading and Writing Class

\section{CONCLUSION}

This research employed qualitative study to analyze the perspectives of the teacher and the students toward the reading materials in ERW class according to the first principle of ER by Day and Bamford (2002). From this study, the writers found out that the teacher and the students shared different perspectives toward the reading materials in ERW class. While the materials should be easy, some students who referred to the materials in the class thought that the materials were not easy. However, there were still some students who said that the materials were still easy and understandable despite the fact that there were some hard words. Unlike the ER principle that advised ER class to have easy materials, some students preferred to have a hard reading material because they thought that they would not improve if they only read easy materials. The students also thought that the materials were not adjusted to each of them; however, some students still consider the reading materials were easy to understood. On the other side, the teacher thought that she has given appropriate materials, the materials given in the class were adjusted to the level of general first semester students. Similar like the students, the teacher thought that the materials should not be too easy and too hard, the materials should be in accordance with the learners' levels.

In conclusion, there were some violations in implementing the first principle of ER by Day and Bamford (2002). The reason was because the nature of the class was not pure ER. The class was unique because it had two different materials namely selected materials by the teacher and materials from the website. Because of the limited knowledge of Extensive Reading, in the interview, the students focused more on in-class activities that referred to the teacher's selected materials that were actually more into intensive reading rather than ER; therefore, a deeper understanding of extensive reading is needed.

There were limitations from the study. Firstly, this study only analyzed a small sample group that consisted of 10 students and 1 teacher from English Department of Petra Christian University. Secondly, the learning was an online learning because of COVID 19 pandemic in Indonesia. Because of that, it was hard to claim that the findings were generalizable to other contexts. Therefore, the writers suggested that the further research could employ a quantitative approach with more participants. The future research could also add more variables to make the research more generalizable such as the English language proficiency, age, university, and learning medium (online and offline learning).

\section{REFERENCES}

Anandari, C. L., \& Iswandari, Y. A. (2019). Extensive reading in Indonesian schools: a successful story. TEFLIN Journal, 30(2), 137-152.

Arifuddin, A. (2018). Students' perception in the impact of Extensive Reading course (Undergraduate Thesis, Islamic University of Indonesia). Retrieved from https://dspace.uii.ac.id/handle/123456789/7559

Barnes, B. D., \& Lock, G. (2013). Student Perceptions of Effective Foreign Language Teachers: A Quantitative Investigation from a Korean University. Australian Journal of Teacher Education, 38(2). http://dx.doi.org/10.14221/ajte.2013v38n2.2

Day, R., \& Bamford, J. (2002). Top ten principles for teaching Extensive Reading. Reading in a Foreign Language, 14(2), 136-141. 
Day, R. R., \& Bamford, J. (2010). The benefits of extensive reading (ER). Available: http://www.oupe./es/es/ELT/Readers/bookworms/Recursos\%20Destacados/the\%20benefits \%20of\%20extensive\%20reading.pdf Accessed Jul 2020.

Day, R. R., Bamford, J., Renandya, W. A., Jacobs, G. M., \& Yu, V. W.-S. (1998). Extensive Reading in the Second Language Classroom. RELC Journal, 29(2), 187-191. https://doi.org/10.1177/003368829802900211

Imamura, K. (2020). Semi-structured Interviews on Extensive Reading for Japanese University Students. Extensive Reading World Congress Proceedings, 5,127-136.Semi-structured Interviews on Extensive Reading for Japanese University StudentsKazuhiro IMAMURA Mukogawa University 